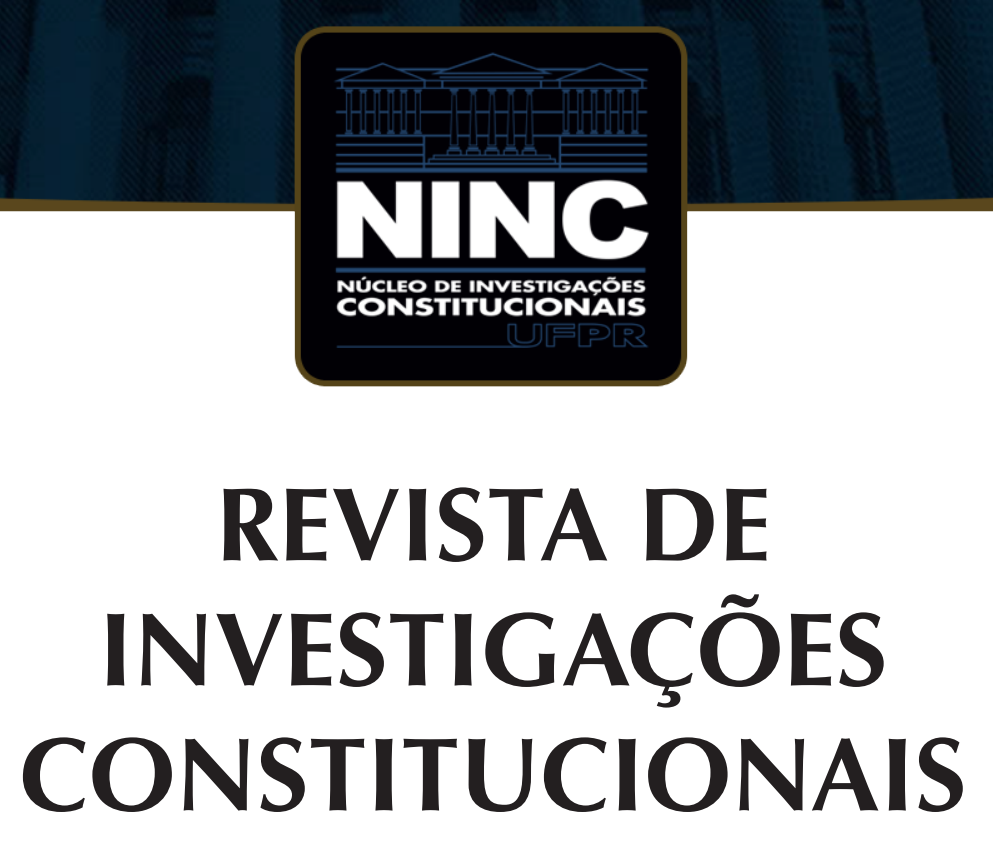

JOURNAL OF CONSTITUTIONAL RESEARCH

vol. 6 | n. 3 | setembro/dezembro 2019 | ISSN 2359-5639 | Periodicidade quadrimestral Curitiba | Núcleo de Investigações Constitucionais da UFPR | www.ninc.com.br 


\title{
Popular demands related to sports in the National Constituent Assembly of Brazil*
}

\section{As demandas populares relativas ao esporte na Assembléia Nacional Constituinte do Brasil}

\author{
FELIPE CANAN ${ }^{1, * *}$ \\ 'Universidade Estadual do Oeste do Paraná - UNIOESTE (Cascavel-PR, Brasil) \\ felipe.canan@gmail.com \\ https://orcid.org/0000-0002-9450-778X
}

FERNANDO AUGUSTO STAREPRAVO $11, * * *$

"Universidade Estadual de Maringá (Maringá-PR, Brasil) fernando.starepravo@hotmail.com https://orcid.org/0000-0002-1655-998X

Recebido/Received: $15.03 .2019 /$ March $15^{\text {th }}, 2019$ Aprovado/Approved: $25.11 .2019 /$ November $25^{\text {th }}, 2019$

\section{Abstract}

The objective was to analyze the popular suggestions related to sports and sports democratization made to the last Brazilian National Constituent Assembly, registered in the Computer Support System to the Constituent, electronic platform created to subsidize the construction of the Constitution of 1988. These suggestions represented the only form of true direct democracy in the constituent process. This is a descriptive article, with data collected in the year 2017. The sum of 415 (32\%) from a total of 1,289 popular suggestions related to the theme

\section{Resumo}

Objetivou-se analisar as sugestões populares relativas ao esporte e à democratização esportiva feitas à última Assembleia Nacional Constituinte brasileira, cadastradas no Sistema de Apoio Informático à Constituinte, plataforma eletrônica governamental criada para a construção da Constituição de 1988. Tais sugestões representaram a única forma de democracia direta plena no processo constituinte. Trata-se de um artigo de caráter descritivo, sendo os dados coletados no ano de 2017. Foram analisadas 415 (32\%) do total de 1.289 sugestões populares relacionadas ao tema

Como citar esse artigo/How to cite this article: CANAN, Felipe; STAREPRAVO, Fernando Augusto. Popular demands related to sports in the National Constituent Assembly of Brazil. Revista de Investigações Constitucionais, Curitiba, vol. 6, n. 3, p. 595620, set./dez. 2019. DOI: 10.5380/rinc.v6i2.65472.

*The present article counted with financial support of CAPES-DS Scholarship, doctorate level, for its accomplishment.

** Professor do curso de Educação Física da Universidade Estadual do Oeste do Paraná - UNIOESTE (Cascavel-PR, Brasil). Doutor em Educação Física pela UEM. Mestre em Educação Física pela UFPR. Especialização em Administração Esportiva pela UFPR. Especialização em Fisiologia do Exercício pela UGF. Graduação em Licenciatura Plena em Educação Física pela PUC-PR. Graduação em Direito pela UNIPAR. É Secretário Estadual do CBCE-PR (gestão 2018-2019) e membro do Comitê Científico do GTT de Políticas Públicas do CBCE. E-mail: felipe.canan@gmail.com.

*** Professor do Departamento de Educação Física da Universidade Estadual de Maringá (Maringá-PR, Brasil). Doutor em Educação Física pela UFPR. Mestre em Educação Física pela UFPR. Graduação em Educação Física pela UFPR. E-mail: fernando. starepravo@hotmail.com. 
"sport" were analyzed. In general, the majority of the suggestions requested more state support for sports, while many suggestions were not appropriate for a national constitution, and approximately $24 \%$ of the suggestions more objectively called for sports democratization. Although these suggestions could inform constituents about popular demands regarding sports, there was prioritization of the demands raised by entities representing the organized sports sector.

Keywords: Federal Constitution; public policy; democracy; right to sport; popular participation.. "esporte". A maioria das sugestões pleiteava genericamente mais apoio estatal ao esporte, muitas sugestões apresentaram-se pouco apropriadas para serem inseridas em uma constituição nacional e aproximadamente $24 \%$ das sugestões reivindicava mais objetivamente uma democratização esportiva. Embora tais sugestões pudessem informar os constituintes sobre demandas populares frente ao esporte, houve priorização das demandas suscitadas por entidades representativas do setor esportivo organizado.

Palavras-chave: Constituição Federal; políticas públicas; democracia; direito ao esporte; participação popular.

\section{CONTENTS}

1. Introduction; 2. Popular participation in politics - direct democracy and representative democracy; 3. Methodology; 4. Results and discussion; 4.1. The three forms of direct popular participation provided in the ANC Internal Regulations; 4.2. The draft constitution and sociological value of the SAIC; 4.3. Sports and the right to sport from the suggestions registered in the SAIC; $\mathbf{5}$. Final considerations; $\mathbf{6}$. References.

\section{INTRODUCTION}

The most recent Brazilian constitutional process, which resulted in the promulgation of the Constitution of the Federative Republic of Brazil (CF) ${ }^{1}$, formally began on June 28, 1985, with the official proposal for a National Constituent Assembly (ANC) by the Republic at that time, approved by Congress on November 28th, 1985.

The ANC began its work on February 1st, 1987, and the exercise of representative democracy was carried out by federal deputies and senators elected through their respective mandates and not exclusively constituent power. For this reason, the ANC was a congressional rather than exclusive assembly. According to Santos ${ }^{2}$, the fact that the constituents were political agents elected to exercise a legislative function, rather than a constituent function, would have been contradictory, leading to divergences in public opinion and weakening the legitimacy of the constitution that would be built.

However, despite doubts about the character of the ANC, the CF was known as a Citizen Constitution, both in reference to its construction process, in which broad popular participation was proposed and observed, and its formal/material content,

\footnotetext{
BRASIL. Constituição da República Federativa do Brasil de 1988, de 05 de outubro de 1998. Diário Oficial da União, Brasília, DF, 05 de outubro de 1998. Available at: <http://www.planalto.gov.br/ccivil_03/constituicao/constituicao.htm>. Last accessed: 15 mar. 2019.

2 SANTOS, Flávia da Cruz. Procurando o lazer na constituinte: sua inclusão como direito social na Constituição de 1988. Campinas, 2011. 178 f. Dissertação (Mestrado) - Faculdade de Educação Física da Universidade Estadual de Campinas. p. 39-41.
} 
which encompasses a wide range of issues, including the establishment of the Democratic Rule of Law and the consequent broad expectation of guaranteeing fundamental rights.

In relation to the construction process, which is of particular interest in this article, it is important to understand how popular participation took place within the ANC, with respect to the exercise of direct democracy. For this analysis it is necessary, initially, to be familiar with the functioning of the ANC, presented in general lines in Table 1, with the forms of direct popular participation highlighted in bold.

\begin{tabular}{|c|c|}
\hline \multicolumn{2}{|c|}{$\begin{array}{l}\text { TABLE 1: GENERAL LINES OF THE FUNCTIONING OF THE NATIONAL CONSTITUENT } \\
\text { ASSEMBLY. }\end{array}$} \\
\hline Stage & Operation \\
\hline Preliminary & $\begin{array}{l}\text { Proposition of suggestions on the part of the citizens, from initiative } \\
\text { of the Federal Senate prior to the creation of the Internal Regulation of } \\
\text { the ANC; creation of the Internal Regulation; proposition of sugges- } \\
\text { tions by the constituents themselves and representative entities of } \\
\text { social segments. }\end{array}$ \\
\hline $\begin{array}{l}\text { Themed } \\
\text { Subcommittees }\end{array}$ & $\begin{array}{l}\text { Meetings with entities representing social segments; presentation of } \\
\text { the Rapporteur's Preliminary Draft; amendments thereto; presentation } \\
\text { of the Preliminary Draft of the Subcommittee. }\end{array}$ \\
\hline $\begin{array}{l}\text { Themed } \\
\text { Commissions }\end{array}$ & $\begin{array}{l}\text { Amendments to the Preliminary Draft of the Subcommittee; presen- } \\
\text { tation of the First Substitute of the Rapporteur; amendments thereto; } \\
\text { presentation of the Second Substitute of the Rapporteur; amendments } \\
\text { thereto; presentation of the Preliminary Draft Commission. }\end{array}$ \\
\hline $\begin{array}{l}\text { Commission } \\
\text { in } \\
\text { systematization }\end{array}$ & $\begin{array}{l}\text { Presentation of Draft Bill for the Constitution of the Rapporteur; amend- } \\
\text { ments thereto; presentation of the Draft Constitution of the Rappor- } \\
\text { teur and Draft Constitution (identical to the draft Constitution of the } \\
\text { Rapporteur); amendments thereto (possibility of popular amend- } \\
\text { ments); presentation of the First Substitute of the Rapporteur; amend- } \\
\text { ments thereto; presentation of the Second Substitute of the Rapporteur; } \\
\text { amendments thereto; presentation of the Draft Constitution (A). }\end{array}$ \\
\hline Plenary & $\begin{array}{l}\text { Amendments to the Draft Constitution }(A) \text {; presentation of the Draft } \\
\text { Constitution (B); amendments thereto; presentation of the Draft Consti- } \\
\text { tution (C). }\end{array}$ \\
\hline $\begin{array}{l}\text { Editorial } \\
\text { Commission }\end{array}$ & $\begin{array}{l}\text { Presentation of proposals for exclusively editorial changes to the Draft } \\
\text { Constitution }(C) \text {; presentation of the Draft Constitution (D) - Final Writ- } \\
\text { ing; promulgation. }\end{array}$ \\
\hline
\end{tabular}


As a very general explanation, the logic of the functioning of the ANC was through the discussion, deliberation, and construction of Constitution projects related to specific topics within each subcommittee and, subsequently, each thematic commission. From the suggestions sent by institutions and the constituents themselves to the President of the ANC and also from meetings with entities representing social segments, it was up to the rapporteur of each subcommittee to suggest the first project related to the respective themes. This project was peer-reviewed and a substitute constructed. This was also evaluated, reaching the draft Constitution of the subcommittee. The commission performed a similar procedure, covering the themes from a series of subcommittees. The draft Constitution of each commission arrived at the commission of systematization and then the plenary, both of which, through procedures similar to those previously mentioned, arrived at the draft Constitution sent to the Editorial Committee, for final textual adjustments.

Regarding direct popular participation, as can be seen from the highlighted phrases in Table 1, four possibilities were foreseen. Three of these were laid down by the ANC Internal Regulations ${ }^{3}$, requiring the intermediation of institutions between citizens and constituents, and will be discussed briefly at the beginning of the discussion of the article. The other possibility, initially called "Tell People" and subsequently "Draft Constitution", was laid down by the Internal Rules, created by the Constitution and Justice Commission of the Federal Senate in 1985 and put into practice in 1986.

The Constitution Project, which was the only form of full direct citizen participation, allowed anyone, regardless of their relationship with an institution, to freely send their demands and propositions to the ANC. This procedure was carried out by completing one or more of the fifty million standard forms that could be withdrawn from government and political party agencies ${ }^{4}$. "In total, 72,719 suggestions were collected throughout the country and the result of the compilation of the suggestions was the creation of the SAIC - Computer Support System to the Constituent database" ${ }^{\prime \prime}$, containing, in addition to the suggestion itself, the identification of the proponent and the consignee (one or more constituents).

Sport is among the subjects indexed in the SAIC. Until the enactment of the CF in 1988, due to the dictatorial regimes present in Brazil since 1937, the national sports organization at the federal level was centralized by state dirigisme and directed to the

\footnotetext{
3 ASSEMBLÉIA NACIONAL CONSTITUINTE. Ano I - $\mathbf{n}^{\circ} 33$ - Resolução $\mathbf{n}^{\circ} \mathbf{2}$, de 1987. Dispõe sobre o Regimento Interno da Assembléia Nacional Constituinte. Brasília: Assembléia Nacional Constituinte, 1987a. The forms of popular participation set forth in the ANC Internal regulations will be presented forward.

4 MONCLAIRE, Stéphane (Org.). A constituição desejada: SAIC: as 72.719 sugestões enviadas pelos cidadãos brasileiros à Assembléia Nacional Constituinte. Vol. 1. Brasília: Senado Federal; Centro Gráfico, 1991. p. 34.

5 CÂMARA DOS DEPUTADOS. Sugestão dos Cidadãos. 2017. Available at <http://www2.camara.leg.br/ atividade-legislativa/legislacao/Constituicoes_Brasileiras/constituicao-cidada/o-processo-constituinte/sugestao-dos-cidadaos>. Last accessed: 15 mar. 2019.
} 
sports elite, especially professional football. There was little freedom of decision and action for private sports institutions and actions regarding sports for all were still incipient; sporting practice was not treated as a right of the people 6 . However, despite the undemocratic nature of the sporting organization up to that time, sports and the right to sport ended up being constitutionalized by the CF, which in the caput of Article 217 states: "It is the duty of the State to promote formal and non-formal sporting practices, such as the right for everyone"

Considering that the Constitution Project was the only form of true direct democracy in the constituent process of the CF and that both in the Subcommittee on Education, Culture and Sports and in the Commission on Family, Education, Culture and Sports, Science and Technology and the Communication of ANC, the thematic right to sport was of little incident ${ }^{8}$, the objective of this article is to analyze the popular suggestions related to sports registered in the SAIC and to identify if there was any demand for the democratization of sports and its condition in law.

No precedents were found in the literature studying these suggestions. The analysis may fill a gap in the history of popular participation in Brazilian sports, providing important subsidies into insights on the possibility of the constitutional text regarding sports and the right to sport being representative or not of popular expectations. At the same time, the analysis contributes by removing from oblivion an important database on popular demands regarding sports. The other forms of direct democracy carried out in the ANC, since they require intermediaries and have already been in some way explored in the literature ${ }^{9}$ will only be contextualized in this article.

\footnotetext{
6 CANAN, Felipe; SANTOS, Luciana Letícia Sperini Rufino dos; STAREPRAVO, Fernando Augusto. Panorama geral sobre políticas de esporte no Brasil. Caderno de Educação Física e Esporte, Marechal Cândido Rondon, v. 15, n. 1, jan./jun. 2017. p. 17-20.

7 BRASIL. Constituição da República Federativa do Brasil de 1988, de 05 de outubro de 1998. Diário Oficial da União, Brasília, DF, 05 de outubro de 1998. Available at: <http://www.planalto.gov.br/ccivil_03/constituicao/constituicao.htm>. Last accessed: 15 mar. 2019.

8 CANAN, Felipe. Compreendendo o direito ao esporte no Brasil - constitucionalização, teleologia e dogmática. Maringá, 2018. 503 f. Tese (Doutorado) - Centro de Ciências da Saúde da Universidade Estadual de Maringá. About the constitutionalisation of the right to sport, see chapter 3.

9 Examples in: CANAN, Felipe. Compreendendo o direito ao esporte no Brasil - constitucionalização, teleologia e dogmática. Maringá, 2018. 503 f. Tese (Doutorado) - Centro de Ciências da Saúde da Universidade Estadual de Maringá; SANTOS, Flávia da Cruz. Procurando o lazer na constituinte: sua inclusão como direito social na Constituição de 1988. Campinas, 2011. 178 f. Dissertação (Mestrado). Faculdade de Educação Física da Universidade Estadual de Campinas; and LINHALES, Meily Assbú. A trajetória política do esporte no Brasil: interesses envolvidos, setores excluídos. Belo Horizonte, 1996. 221 f. Dissertação (Mestrado) - Faculdade de Filosofia e Ciências Humanas da Universidade Federal de Minas Gerais.
} 


\section{POPULAR PARTICIPATION IN POLITICS - DIRECT DEMOCRACY AND REPRESENTATIVE DEMOCRACY}

According to the precepts of Bobbio ${ }^{10}$, the democratic regime is summarized by a set of rules and procedures for forming collective decisions, with foresight and facilitation of the broadest possible participation of stakeholders. The author argues that there are two systems of democracy, both resulting from popular sovereignty, but different regarding their form of assignment and criteria for collective decision-making; the first being representative democracy and the second direct democracy.

Representative democracy is derived eminently from the fact that, considering the extensive and populous territory of modern states, it would be impracticable to organize a system that could guarantee the equal participation of all individuals in collective decisions ${ }^{11}$. Given this situation, the idea of political representativeness arises, which is broadly based on the choice of representatives of the community to make political decisions on behalf of voters.

"Collective deliberations, that is, deliberations concerning the whole collectivity, are not taken directly by those who form part of it but by persons elected for this purpose $^{\prime \prime 2}$. According to the author there are general representations and representations that act on behalf of specific groups, so that often a real bond is not established between the elect and those who elected them. By being affiliated with and/or defending the interests of specific groups, elected representatives often fail to defend collective interests, so that political decisions do not always represent social needs/demands.

This does not mean that elected political agents necessarily act in defense of their own or particular interests, but may also offer political and public actions in order to meet demands that they consider to be priorities ${ }^{13}$. That is, within a political agenda, the elected agents themselves decide on the demands that they believe are the main ones, even if they are often only understood in the light of the influences of specific social groups that, for whatever reason, acquire the potential/power to exercise these influences. This distance and/or disharmony between the performance of the elected agents and the needs of the collectivity can make the political environment restricted

\footnotetext{
10 BOBBIO, Norberto. O futuro da democracia - uma defesa das regras do jogo. Rio de Janeiro: Paz e Terra, 2009. p. 40-63.

11 PEREIRA, Antônio Kevan Brandão. A concepção democrática de Bobbio: uma defesa das regras do Jogo. Revista Estudos de Política, Campina Grande, v. 1, n.1, p. 53-67, 2012. p. 56-58.

12 BOBBIO, Norberto. O futuro da democracia - uma defesa das regras do jogo. Rio de Janeiro: Paz e Terra, 2009. p. 56.

13 STAREPRAVO, Fernando Augusto. Políticas públicas para o esporte e lazer: conselhos municipais de esporte e lazer e outras formas de participação direta. In: Anais do XV Congresso Brasileiro de Ciências do Esporte e Il Congresso Internacional de Ciências do Esporte. Recife: CBCE, 2007. p. 5-7.
} 
and inaccessible to other agents, generating a collective subsumption of the decisions of the representatives.

As a result of this possibility of distance opened by representative democracy between decisions and social needs, certain difficulties arise for the consolidation of a broad democracy, which refers to the idea of direct democracy. For Bobbio ${ }^{14}$, in direct democracy there is an expansion of mechanisms of participation and decision, in which the individual themself participates in the deliberations of their interest without the need for an intermediary/mediator.

It is in this sense that, for Araujo, Jara and Magalhães ${ }^{15}$, "[...] popular participation in public management is necessary to guarantee the democratic process and awaken the feeling of co-authoring on objective actions of public policies". The participation of citizens in political decisions characterizes the decentralization of state power, transferring jurisdictions or powers from the center to the periphery ${ }^{16}$.

Alternative means are created for closer participation of agents or social segments in political decisions, equating or diminishing the power of elected political agents ${ }^{17}$. A sectoral municipal council with deliberative power is an example because "Councils institutionalize the participation of civil society in the processes of policy formulation, implementation, and political evaluation"18. They form a collegiate agency composed of leaders of institutions, groups, or social sectors related to the theme for which the council was created. This is a form of public control of government actions and decisions, besides discussing and often deliberating on issues of their competence, establishing popular leaderships and seeking to resolve conflicts ${ }^{19}$. At the municipal level they act towards the local demands and in cases where they have deliberative power they can impose on the elected political agent the decisions to be taken regarding certain themes.

14 BOBBIO, Norberto. O futuro da democracia - uma defesa das regras do jogo. Rio de Janeiro: Paz e Terra, 2009. p. 40-63.

15 ARAUJO, Silvana Martins de; JARA, laci de Costa; MAGALHÃES, Ywcy Crystiano da Silva. O processo de participação democrática e controle social nas políticas públicas de esporte e lazer. In: ARAUJO, Silvana Martins (Org.). Conselhos estaduais de esporte e lazer no Nordeste brasileiro: participação popular e controle social em questão. São Luís: Edufma, 2011. p. 71.

16 ARRETCHE, Marta. Mitos da descentralização: maior democracia e eficiência nas políticas públicas? Revista Brasileira de Ciências Sociais, São Paulo, v. 11, n. 31, p. 44-66, 1996. p. 52; GUINMARÃES, Maria do Carmo Lessa. O debate sobre a descentralização de políticas públicas: um balanço bibliográfico. Organizações \& Sociedade, Salvador, v. 9, n. 23, p. 1-17, jan./abr. 2002. p. 2.

17 BOBBIO, Norberto. O futuro da democracia - uma defesa das regras do jogo. Rio de Janeiro: Paz e Terra, 2009. p. 40-63.

18 BRUST, Cristina; BAGGIO, Isabel Cristina; SALDANHA FILHO, Matheus Francisco. Repensar a gestão das políticas públicas de esporte e lazer: o caso de Santa Maria/RS. Motrivivência, Florianópolis, a. XVIII, n. 27, p. 179-185, dez. 2006. p. 183.

19 BRUST, Cristina; BAGGIO, Isabel Cristina; SALDANHA FILHO, Matheus Francisco. Repensar a gestão das políticas públicas de esporte e lazer: o caso de Santa Maria/RS. Motrivivência, Florianópolis, a. XVIII, n. 27, p. 179-185, dez. 2006. p. 182-183. 
This does not mean that in direct democracy all citizens participate in all decisions, as this would be materially impossible due to the complexity of societies ${ }^{20}$. Even in the case of direct democracy, a representation of content can exist, as in the example of the city council, not all citizens participate in this, but representatives of certain social segments. Although these representatives are more diverse and closer to the community sectors than commonly occurs in relation to the elected political agents, they are nevertheless representatives.

At the same time, direct democracy does not necessarily mean the substitution of representative democracy, and there may be concomitance and even complementarity between the two, thus, coming as close as possible to a true democracy, considering population size and the consequent complexity of contemporary societies ${ }^{21}$.

\section{METHODOLOGY}

The article adopts descriptive objectives and a qualitative-quantitative approach. Descriptive research aims to describe populations or phenomena and/or establish relations between variables. The phenomenon investigated in this article is direct democracy in the $\mathrm{ANC}^{22}$.

The documentary corpus consists of the suggestions of the population for the ANC registered in the SAIC and available on the Federal Senate of Brazil website ${ }^{23}$. There are a total of 72,719 registered suggestions, of which 1,289 are identified by the descriptor "sport" and its derivatives searched in the Portuguese language. The search on the website allows all suggestions that contain the descriptor used to be found, if the descriptor is present in any of the fields on the form completed by the citizen (name, address, location, personal data - sex, area resident, school graduation, marital status, age range, income range, activity - and suggestion) or in the terms catalogued and/ or indexed by system operators. Of the total, $415(32 \%$ of 1,289$)$ randomly selected suggestions were analyzed. Regarding the analysis of the suggestions, a qualitative approach was chosen, based on the content analysis technique of Bardin ${ }^{24}$. The popular suggestions were categorized respecting the three steps presented by the author: pre-analysis, material exploration, and treatment of results. Although, due to the objectives

\footnotetext{
20 BOBBIO, Norberto. O futuro da democracia - uma defesa das regras do jogo. Rio de Janeiro: Paz e Terra, 2009. p. $40-63$.

21 BOBBIO, Norberto. O futuro da democracia - uma defesa das regras do jogo. Rio de Janeiro: Paz e Terra, 2009. p. 40-63.

22 GIL, Antonio Carlos. Métodos e técnicas de pesquisa social. 6. ed. São Paulo: Atlas, 2008. p. 44.

23 SENADO FEDERAL. Atividade legislativa - bases históricas. 2017. Available at: <http://www.senado.gov. br/atividade/baseshist/bh.asp\#/>. Last accessed: 15 mar. 2019.

24 BARDIN, Laurence. Análise de conteúdo. São Paulo: Edições 70, 2011.
} 
of the article, there is special interest in the theme of the right to sport, no category of analysis was created a priori, all emerging from the material exploration itself, with consequent inferences and interpretations. Throughout the article, the explanation of each category is given initially by a brief presentation of the respective characteristics and coding criteria and later by the presentation of six examples of suggestions that illustrate both the homogeneity and scope of the category.

A quantitative analysis was performed, in addition to presentation in terms of frequency and percentage of suggestions related to each category. When a suggestion covered more than one category, it was placed in what appeared to be the main demand of the applicant. The sociological data of the proponents and the consignees of the suggestions that, according to Monclaire ${ }^{25}$, are problematic due to misunderstandings in the form completion by the citizens or registration by the SAIC, are at the moment not the specific object of analysis. The theoretical framework adopted for discussion was the match formed between direct and representative democracy, especially under the assumptions of Bobbio ${ }^{26}$.

\section{RESULTS AND DISCUSSION}

\subsection{The three forms of direct popular participation provided in the ANC Internal Regulations}

The three forms of direct democracy provided in the ANC Internal Regulation concern the possibility of popular participation through institutions, called representatives of social segments, during the constituent process of entities. The Internal Regulation $^{27}$ provided:

- in $\S 11$ of Article 13, that such entities could send suggestions of propositions addressed to the ANC President, later sent to the responsible committees and subcommittees;

- in Article 14, that each subcommittee should allocate 5 to 8 meetings for the hearing of entities, including the possibility of making suggestions;

- In Article 24, popular amendments would be possible in the first draft constitution presented by the Commission of Systematization, provided that they were signed

25 MONCLAIRE, Stéphane (Org.). A constituição desejada: SAIC: as 72.719 sugestões enviadas pelos cidadãos brasileiros à Assembléia Nacional Constituinte. Vol. 1. Brasília: Senado Federal; Centro Gráfico, 1991. p. 47-51.

26 BOBBIO, Norberto. O futuro da democracia - uma defesa das regras do jogo. Rio de Janeiro: Paz e Terra, 2009. p. $40-63$.

27 ASSEMBLEIA NACIONAL CONSTITUINTE. Ano I - $\mathbf{n}^{\circ} \mathbf{3 3}$ - Resolução $\mathbf{n}^{\circ} \mathbf{2}$, de 1987. Dispõe sobre o Regimento Interno da Assembléia Nacional Constituinte. Brasília: Assembléia Nacional Constituinte, 1987a. 
by 30,000 or more voters, organized by at least three legally constituted representative entities.

In the case of sports, few entities sent specific propositions to sports and none suggested amendments to the first draft Constitution of the Commission of Systematization. It can be verified that in these stages of the ANC, direct democracy was little exercised by the institutions related to sports. It was not possible to identify if the limited popular participation in these phases was due to lack of interest or lack of competence for collective mobilization due to the institutional organization required by the Internal Regulations.

In the case of hearings, in addition to the National Sports Council and the Secretariat of Physical Education and Sports of the Ministry of Education and Culture, federal government bodies responsible for sports issues in the period, some private institutions exclusively representing the formal or organized sports system ${ }^{28}$, composed of the Brazilian Olympic Committee, sports confederations and federations, leagues, clubs and sports association or representatives of different groups of sports agents (athletes, referees, chroniclers, etc.) were invited. Representative entities of other social segments, such as the academic area of Physical Education, physical education at school, clubs and associations aimed at amateur competitive sports, municipality or residents associations were not invited to discuss sports issues. In this constituent stage, in relation to sports, it is perceived that there was only partial direct popular participation as it is exercised only by entities selected by the constituents themselves and only institutions were permitted, not individuals.

If analyzed under the assumptions of Bobbio ${ }^{29}$, it is possible to perceive that the way in which this mixed democratic exercise was performed, with direct participation through institutional representation, actually demonstrated a representation of interests of a certain social segment and not necessarily of collectivity. Since only the constituent entities of the organized sports system were selected to participate in the court hearings, it seems natural that only their interests dealt with in the ANC, as legitimate interests of the so-called "national sports community", were defended.

Considering that during the constituent period, ideas about sports for all and the right to sport and physical education were already known and that this was already a compulsory school discipline, it is understood that not all entities that formed part of the national sports community had the opportunity for representation and direct participation in the ANC hearings stage. This fact could have been minimized

28 ASSEMBLEIA NACIONAL CONSTITUINTE. VIII - Comissão da Família, da Educação, Cultura e Esportes, da Ciência e Tecnologia e da Comunicação; VIII-a - Subcomissão da Educação, Cultura e Esportes; Anteprojeto. Brasília: Assembléia Nacional Constituinte, 1987b. p. 22.

$29 \mathrm{BOBBIO}$, Norberto. $O$ futuro da democracia - uma defesa das regras do jogo. Rio de Janeiro: Paz e Terra, 2009. p. 40-63. 
by the participation of the National Council of Sports and the Department of Physical Education and Sports of the Ministry of Education and Culture, public agencies that to some extent defended greater sports democratization, besides the organized sports system. However, as pointed out by Canan ${ }^{30}$, throughout the ANC, discussions and deliberations prevailed related to the liberalization of sports institutions deprived of state-owned centralization present until then and also respect for the need and forms of public financing and/or tax incentives to these institutions. There was little concern for school physical education, sport for all, or the right to sport.

\subsection{The Draft Constitution and sociological value of the SAIC}

From the previous discussion, it follows that the only stage of true direct democracy for the construction of the CF was the one held before the formal constitutional process, through the Draft Constitution, which resulted in the popular suggestions registered in the SAIC. However, this Draft and its unfolding presented their own problems and contradictions. For example, only $1.4 \%$ of the distributed forms were sent to the ANC; there was not necessarily any representativeness of the Brazilian population among the proponents, since not all citizens would have the socio-cultural conditions to participate in the constituent process, and/or not all would believe that their suggestions would be taken into account; filling in the identification and recipients data was optional and often omitted; the fact that it is a written document could omit the truth behind the form, which could be influenced or manipulated by a particular social organization (school, church, political party, etc.); the space for completing the suggestions was small considering the total space of the form; and the indexing of the data was performed in an unprofessional and unscientific way, so that information was often supplemented or suppressed at random by those responsible; among others ${ }^{31}$.

Another problem regarding the SAIC lies not in the system itself, but in its use by the ANC, since the Internal Regulations did not establish protocols in this regard.

30 CANAN, Felipe. Compreendendo o direito ao esporte no Brasil - constitucionalização, teleologia e dogmática. Maringá, 2018. 503 f. Tese (Doutorado) - Centro de Ciências da Saúde da Universidade Estadual de Maringá. Chapter 3.

31 MONCLAIRE, Stéphane (Org.). A constituição desejada: SAIC: as 72.719 sugestões enviadas pelos cidadãos brasileiros à Assembléia Nacional Constituinte. Vol. 1. Brasília: Senado Federal; Centro Gráfico, 1991. p. 47-82. 


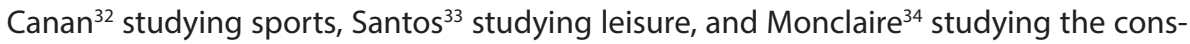
tituent process as a whole identified that the SAIC suggestions were underutilized throughout the ANC. For example, the Rapporteur of the Subcommittee on Education, Culture, and Sports, in presenting the first draft of the Constitution on sport, stated that the SAIC had registered only 25 suggestions for sports ${ }^{35}$, contradicting the 1,289 suggestions identified by this article.

According to Monclaire ${ }^{36}$ it is also possible to make an analogy of the SAIC with a book published with suggestions given by the population of the state of São Paulo. The constituents treated the book with disdain, claiming it to be a sample of the disinformation and ignorance of the people regarding the ANC. For the author, the constituents assumed absolute knowledge and decision-making, little considering the exercise of direct democracy provided by the SAIC or the aforementioned book. On the basis of Bobbio $^{37}$, one can see an overlap between representative democracy and direct democracy, which is aggravated by the ANC being congressional and not exclusive.

Analysis of the popular suggestions registered in the SAIC, besides allowing knowledge of the popular demands related to sports, could contribute to verifying the veracity or not of the mentioned unpreparedness of the population in relation to knowledge about the function of the originating constituent power. Moreover, the problems and contradictions identified in relation to the SAIC do not mean that it has been invalidated. On the contrary, as Monclaire ${ }^{38}$ puts it, this is a unique database in the world and with precious information about popular demands for the constitution that would be created and, more importantly, about several issues considered important by the population. The author only notes that specific studies on SAIC data should take into account the existence of such problems, taking necessary care in the analysis.

32 CANAN, Felipe. Compreendendo o direito ao esporte no Brasil - constitucionalização, teleologia e dogmática. Maringá, 2018. 503 f. Tese (Doutorado) - Centro de Ciências da Saúde da Universidade Estadual de Maringá.

33 SANTOS, Flávia da Cruz. Procurando o lazer na constituinte: sua inclusão como direito social na Constituição de 1988. Campinas, 2011. 178 f. Dissertação (Mestrado). Faculdade de Educação Física da Universidade Estadual de Campinas.

34 MONCLAIRE, Stéphane (Org.). A constituição desejada: SAIC: as 72.719 sugestões enviadas pelos cidadãos brasileiros à Assembléia Nacional Constituinte. Vol. 1. Brasília: Senado Federal; Centro Gráfico, 1991.

35 ASSEMBLÉIA NACIONAL CONSTITUINTE. VIII - Comissão da Família, da Educação, Cultura e Esportes, da Ciência e Tecnologia e da Comunicação; VIII-a - Subcomissão da Educação, Cultura e Esportes; Anteprojeto. Brasília: Assembléia Nacional Constituinte, 1987b. p. 22.

36 MONCLAIRE, Stéphane (Org.). A constituição desejada: SAIC: as 72.719 sugestões enviadas pelos cidadãos brasileiros à Assembléia Nacional Constituinte. Vol. 1. Brasília: Senado Federal; Centro Gráfico, 1991. p. 189-190.

37 BOBBIO, Norberto. O futuro da democracia - uma defesa das regras do jogo. Rio de Janeiro: Paz e Terra, 2009. p. $40-63$.

38 MONCLAIRE, Stéphane (Org.). A constituição desejada: SAIC: as 72.719 sugestões enviadas pelos cidadãos brasileiros à Assembléia Nacional Constituinte. Vol. 1. Brasília: Senado Federal; Centro Gráfico, 1991. p. 19. 
Although there are contradictions regarding the representativeness of popular suggestions and their use within the ANC, the SAIC presents itself as a database of precious sociological value, as the ANC Vice-President, Senator Mauro Benevides mentioned $^{39}$. Thus, the SAIC not only represents a database of suggestions to the ANC, but one of the most complete sources of data on popular demands regarding sports identified in Brazilian history.

At the same time, reinforcing the importance of the SAIC, there are also no precedents of inventories (at least of similar magnitude) that registered popular demands towards sports and their relation with the State. Although large inventories developed in the national scenario by the State or private initiative, such as the "Diagnosis of Physical Education/Sports of Brazil"40, the "Conclusive Report of the Commission for the Reformulation of Sports" ${ }^{41}$, the "Sports Atlas in Brazil"42, or the "National Sports Diagnosis"43 sought to identify different aspects of the Brazilian sports scene, such as legislation, number of participants in each competitive sporting modality, and number of sportspeople by region of the country, etc., none consulted people about their demands in an in-depth manner. The SAIC can thus be considered the most important instrument of direct democracy in the history of Brazilian sports.

\subsection{Sports and the right to sport from the suggestions registered in the SAIC}

Without losing sight of the objectives of the article and the historical and social importance of this database for the area of sports, we reached eight thematic categories of analysis, presented in Table 1, listed in alphabetical order.

\footnotetext{
39 MONCLAIRE, Stéphane (Org.). A constituição desejada: SAIC: as 72.719 sugestões enviadas pelos cidadãos brasileiros à Assembléia Nacional Constituinte. Vol. 1. Brasília: Senado Federal; Centro Gráfico, 1991. p. 5-6.

40 COSTA, Lamartine Pereira da. Diagnóstico de Educação Física/Desportos no Brasil. Brasília: Ministério do Planejamento e Coordenação Geral; Ministério da Educação e Cultura, 1971.

41 MINISTÉRIO DA EDUCAÇÃO E CULTURA, Uma nova política para o desporto brasileiro - esporte brasileiro, questão de Estado (Comissão de Reformulação do Desporto - Relatório Conclusivo). Brasília: Secretaria de Educação Física e Desportos do Ministério da Educação e Cultura, 1985.

42 DACOSTA, Lamartine (Org.). Atlas do Esporte no Brasil. Rio de Janeiro: CONFEF, 2006. Consórcio: Conselho Federal de Educação Física; Serviço Social da Indústria; Serviço Social do Comércio; Federação Nacional das Associações Atléticas Banco do Brasil Associação Cristã de Moços; Confederação Brasileira de Clubes; Comitê Olímpico Brasileiro; Comitê Paraolímpico Brasileiro; Fundação Getúlio Vargas / Escola Brasileira de Administração Pública e Empresas; Fórum Nacional dos Secretários e Gestores Estaduais de Esporte e Lazer; Ministério dos Esportes, 2004.

43 MINISTÉRIO DO ESPORTE. Diagnóstico nacional do Esporte - Diesporte - Caderno 1. Brasília: Ministério do Esporte, 2015
} 


\begin{tabular}{|l|l|l|}
\hline \multicolumn{2}{|c|}{$\begin{array}{l}\text { TABLE 1: CATEGORIES RELATED TO SPORTS AND FREQUENCY AND PERCENTAGE OF SUG- } \\
\text { GESTIONS IN EACH CATEGORY. }\end{array}$} \\
\hline Category & Frequency & Percentage \\
\hline Generic support for sports & 128 & $30.84 \%$ \\
\hline Local or personal demands & 31 & $7.47 \%$ \\
\hline Right to sport & 49 & $11.81 \%$ \\
\hline Amateur sports & 51 & $12.29 \%$ \\
\hline Professional Football & 57 & $13.73 \%$ \\
\hline Sports Lottery & 25 & $6.02 \%$ \\
\hline Other references to the term "sports" & 22 & $5.30 \%$ \\
\hline Others & 52 & $12.53 \%$ \\
\hline Total & 415 & $100 \%$ \\
\hline
\end{tabular}

It can be seen from Table 1 that there was a certain balance between the categories of popular suggestions presented to the ANC. The greatest incidence of suggestions in the category "generic support to sports" can be explained by the fact that this category demonstrates the greatest possibility for comprehensive suggestions, due to its generic nature. In this category, the rule was that the suggestions only mentioned some form of support to sports or demanded it among a range of other activities, especially in schools, as can be seen in the examples in Table 2.

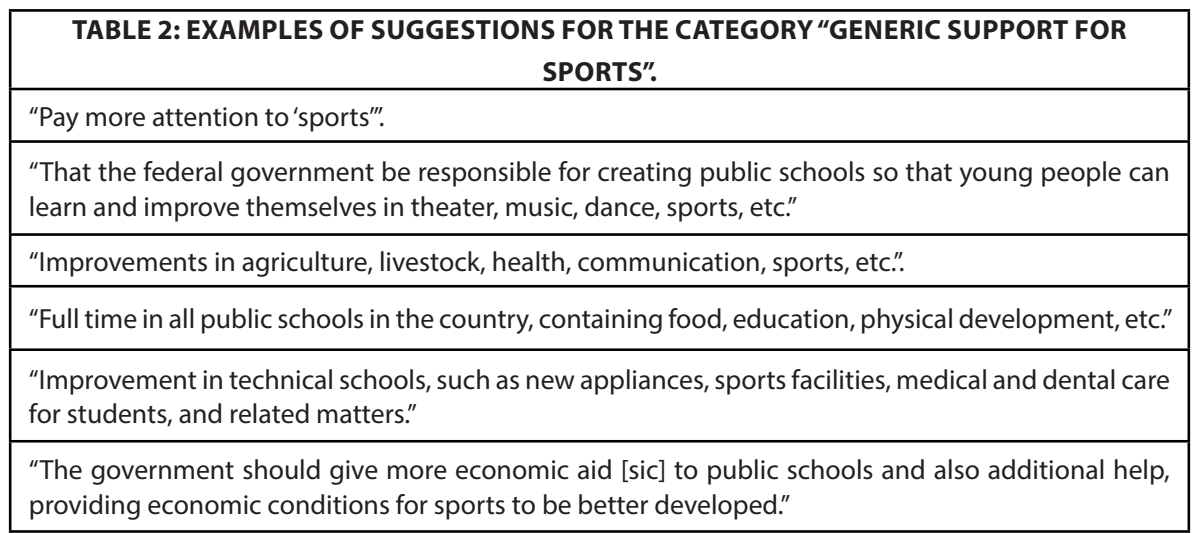

The category "Local or personal demands", in its turn, included suggestions that demanded reparation or encouragement of a specific demand from the community or the citizens themselves, demonstrating a particularistic view of them in relation to the $\mathrm{ANC}$, as if the request were being directed to a local councilor. The examples are given in Table 3. 
TABLE 3: EXAMPLES OF SUGGESTIONS CONCERNING THE CATEGORY “LOCAL OR PERSONAL DEMANDS"

"I come through this, to ask your honor for resources for the leisure of the residents of this municipality who, for the most part, find themselves without the economic conditions to attend [sic] any sports or social institution existing in this municipality".

"We ask delegate Agnaldo Timoteo to build a sport center in Vila Edna."

"I hereby inquire to Mr. President of the Republic. Could you fulfill my wish? I would like the next world cup to be in Brazil."

"I ask that the Minister of Social Security hurry the INPS of Prudente, state of São Paulo, with my special retirement as I was a professional football player ..."

"- I play sports and would like a firm to sponsor me [...]".

"I hope that funds come to our school, which it is very poor, and also to build sport facilities as it does not have them".

The last example presented in Table 3 shows a very common feature of the suggestions sent to the ANC, and even mentioned by Monclaire ${ }^{44}$, in which in many schools, teachers encouraged the students to submit suggestions. At the same time, this category seems to be the one that provides the greatest opportunity for some constituents to understand that the Brazilian people would be unprepared to contribute to the ANC. This point also deserves attention in relation to direct democracy, suggesting that, while it is advisable to conquer a broad democracy, this requires some degree of education and preparation of the citizens for its exercise. In cases where there is education and preparation, direct democracy may be an element pertinent not only of efficiency, but also of the effectiveness of the public machine, reaching the objectives of representing the collectivity and meeting the standards recommended by the literature ${ }^{45}$.

44 MONCLAIRE, Stéphane (Org.). A constituição desejada: SAIC: as 72.719 sugestões enviadas pelos cidadãos brasileiros à Assembléia Nacional Constituinte. Vol. 1. Brasília: Senado Federal; Centro Gráfico, 1991. p. 55-56.

45 Examples in: ARAUJO, Silvana Martins de; JARA, laci de Costa; MAGALHÃES, Ywcy Crystiano da Silva. O processo de participação democrática e controle social nas políticas públicas de esporte e lazer. In: ARAUJO, Silvana Martins (Org.). Conselhos estaduais de esporte e lazer no Nordeste brasileiro: participação popular e controle social em questão. São Luís: Edufma, 2011, p. 17-80; ARRETCHE, Marta. Mitos da descentralização: maior democracia e eficiência nas políticas públicas? Revista Brasileira de Ciências Sociais, São Paulo, v. 11, n. 31, p. 44-66, 1996; BOBBIO, Norberto. O futuro da democracia - uma defesa das regras do jogo. Rio de Janeiro: Paz e Terra, 2009; GUINMARÃES, Maria do Carmo Lessa. O debate sobre a descentralização de políticas públicas: um balanço bibliográfico. Organizações \& Sociedade, Salvador, v. 09, n. 23, p. 1-17, jan./abr. 2002; PEREIRA, Antônio Kevan Brandão. A concepção democrática de Bobbio: uma defesa das regras do Jogo. Revista Estudos de Política, Campina Grande, v. 1, n.1, p. 53-67, 2012; and STAREPRAVO, Fernando Augusto. Políticas públicas para o esporte e lazer: conselhos municipais de esporte e lazer e outras formas de participação direta. In: Anais do XV Congresso Brasileiro de Ciências do Esporte e II Congresso Internacional de Ciências do Esporte. Recife: CBCE, 2007. p. 1-9. 
However, although many suggestions, particularly concerning the categories "Local and personal demands", "Professional football" (Table 6), and "Others" (Table 9), demonstrate that many citizens do not seem to have much sense of what the constitutional process was about, the generalization made by the delegates also represents a presumptuous and disrespectful stance. As representatives of the people it seems sensible that they at least take an interest in the content of the SAIC, absorbing what is pertinent for inclusion in a constitution and/or presenting more incidents among the suggestions. At the same time, precisely because several suggestions were not restricted to issues that would normally be expected to be included in a constitution, the SAIC gains importance as a sociological tool, as it extrapolates the constituent scope and ends up portraying popular demands in general.

The "Right to sport" category, for example, unlike "Local and personal demands" and "Professional football" presents some more elaborate demands that seem to belong to people more directly related to the sports universe and the physical culture in general, showing itself to be important for the exercise of direct democracy in sports. In this category, suggestions are mentioned that, although not necessarily expressly claiming the right to sport, end up somehow referring to it and to questions of sports democratization in general, as shown in the examples in Table 4.

\section{TABLE 4: EXAMPLES OF SUGGESTIONS FOR THE CATEGORY “RIGHT TO SPORT”.}

"I am a physical education teacher and have already written, when asked, suggestions on Brazilian sport. 1 - it is necessary that physical education be implemented from the 1st Grade and administered by physical education teachers. 2 - the culture and civility of a population is directly proportional to the number of Olympic medals the country has won. 3 - sports must be seen and supported with better eyes - since its initiation in the 1st Grade of Primary School and (as a natural activity geared to physical education-sport), in Secondary School, with great care through Higher Education, the graveyard of potentialities and talents."

"That the state seeks to give greater support and encouragement to the student from Primary School in sports, enacting to that end, laws that aim to assure them this right, since it is the source of discoveries of new athletes."

"1- suggestion: creation of federal, state, and municipal networks of sports initiation schools, (similar to the Primary School network). 2- suggestion: - to organize and discipline school sports with a new law. 3- suggestion: - regulate the profession of the physical education teacher. Physics. - to regulate [sic] the installations of the implantations of gymnasiums." 


\begin{abstract}
"That the new constitution refine the state's lines of action within sports, focusing more on the massification of sports through programs of initiation and leisure orientation of people who cannot develop high-level sport. That high level sports be sponsored and promoted by the private initiative, having the state as the organizer and moderator in various federations and confederations, providing better conditions and fiscal incentives for companies that invest in sports, showing them the way and, mainly, the publicity return that sports brings. Physical education, along with food, are fundamental factors in healthy development, the new constitution should adopt a well-defined policy on birth control and the equal distribution of food in schools, encouraging physical education and sports at all levels of society, especially among the least favored classes, who are currently the biggest victims and target of crime and illegal drugs ."

"- it is the obligation of the state to offer, promote, and guarantee the practice of sports in any form, to any person or team that wishes to make use of it".

"... that the right to sport, leisure, and recreation at all levels of education and all social segments shall be guaranteed to the citizen".
\end{abstract}

An interesting fact about these suggestions is that a large number of them were subscribed by Physical Education teachers. Their more elaborate character in relation to the other categories and the fact that they are only the fifth of the eight categories in terms of frequency of suggestions (Table 1) implies that the understanding of sports law and sports democratization was not necessarily a concrete popular demand of the period, but the result of technical/academic knowledge that is still poorly socialized. In addition, in this category, the search for quality assurance in providing services related to Physical Education and sports to the population, including through professional regulation, was quite evident.

In summary, it was possible to notice an understanding of the association of school physical education with initiation and sports massification, with strong traits of the pyramidal model that had been stimulated by the government until then, by which the offer of sports practice in all contexts serves to feed the elite sport, following its functioning logic ${ }^{46}$. This shows that no matter how strongly an idea of sports democratization was outlined, it was still very tied to a vision of sports as a competitive and institutionalized practice, in the form of "sports modality" (athletics, football, swimming, etc.). There was not necessarily thought towards a democratization of physical activities or "sport for all", as described in the European Charter of Sports for All", but mainly towards a greater incentive to the practice of "amateur" competitive sport,

46 CASTELLANI FILHO, Lino. O Estado brasileiro e os direitos sociais: o esporte. In: GARCIA, Carla Cristina; HÚNGARO, Edson Marcelo; DAMASCENO, Luciano Galvão (Org.). Estado, política e emancipação humana - lazer, educação, esporte, saúde como direitos sociais. Santo André: Alpharrabio, 2008. p. 134.

47 MINISTROS EUROPEOS RESPONSABLES DEL DEPORTE. Carta Europea del Deporte para Todos. 1975. Universidad de Córdoba. Available at <https://www.uco.es/deportes/media/documentacion/Carta\%20Europea\%20del\%20Deporte\%20para\%20todos.pdf>. Last accessed: 15 mar. 2019. 
embracing both the child-juvenile public (sports initiation/training) and non-professional adult athletes.

The requests in the "amateur sport" category confirm this view of competition sport as a hegemonic practice in that period in Brazil, to the detriment of general physical culture. Based on the content of the suggestions, amateur sport was not understood as an informal practice or as synonymous with physical activity in general, but as a competitive and institutionalized practice carried out in a non-professional way, that is, without remuneration defined by an employment contract. Essentially it referred to sports modalities different from football, the only sport in which athletes managed to reach the condition of professionals. The suggestions range from a general request for support, to criticizing the salaries paid to some professional football players, and propositions of operational or pedagogical ways to develop amateur sports. The generic suggestions, such as the fourth example in Table 05, were inserted in the category "amateur sport" and not in the category "generic support for sport" because it expressly states the term "amateur".

\section{TABLE 05: EXAMPLES OF SUGGESTIONS CONCERNING THE CATEGORY "AMATEUR SPORT"}

"- incentive established by law through scholarships and reduction in working hours allowing athletes to fund their studies and develop skills. - plans for better use of sport venues in all cities and not just in larger ones".

"As a sportsperson I request greater attention in the legislative changes differentiating the paid professional from the unpaid amateur. Considering that the paid professional is obliged to comply with sporting [sic] laws. Considering the amateur as a leisure sport. Considering professional with 2 substitutions, amateur 5 . Considering that of the 5 substitutes 2 come into play and 3 do not, in this case there are 3 more marginalized athletes who do not go back anymore, this is the cause of amateur sport bankruptcy. Considering greater commitment to school grades for participation in the lower categories".

"Incentive for amateur sport and disincentive to scandalously remunerate professional sports, such as Brazilian football (painful contrast between poverty and national sacrifice to pay such a salutary and fraternal way of living, such as sports)."

"Give more support to amateur sports".

"Professional football does not survive by itself. Benefits to football are an affront to the reigning misery. Unrestricted incentives to general amateur sports".

"- encouraging sports competitions as a cultural factor".

The category "Amateur sport" is directly related to the category "Right to sport" as it aims at more democratic development of sports practices, not limited to elite athletes. However, Article 217 of the $\mathrm{CF}$, in addition to including formal and non-formal 
sporting practices as a right for each person, establishes that there must be "allocation of public resources as a priority for the promotion of educational sports and, in specific cases, for high-performance sports" and that there should be " differentiated treatment for professional and non-professional sports", but does not expressly address amateur sports.

At the same time, it is possible that these demands related to amateur sports have been to some extent treated as secondary due to the growing professionalization that was taking place within classist sports, composed of associations created by private companies for sports practice by employees and/or employers ${ }^{48}$. This form of sports organization, which was originally intended as sports aimed at all members of a company as a way of leisure and health, ended up being largely integrated in the organized sports system. This is because companies, finding in elite sports a way of advertising/ marketing, started to invest and prioritize representative athletes/teams in official competitions, in a kind of semi-professionalism ${ }^{49}$.

An important context of sports for all, thus, began to turn to elite sport, weakening sports offers for citizens in general. The conflict between elite sports and amateur sports, although tacit, was little discussed throughout the ANC, and the greater attention given to the component entities of the organized sports system to the detriment of the SAIC popular suggestions reinforces the perception that only part of the national sports community was privileged, this part being treated as the whole.

The category "Professional football" complements the previous one in the sense of including criticism on the professionalism and salaries of players, but goes further, addressing issues such as the management of the governing bodies and State support to them and to clubs, and complaints in general regarding the national men's football, among others. In this category there seems to be preponderance of sports spectators and not of practitioners, physical education teachers or practice enthusiasts. Some examples that illustrate the category "Professional football" are presented in Table 6.

TABLE 6: EXAMPLES OF SUGGESTIONS CONCERNING THE CATEGORY “PROFESSIONAL FOOTBALL".

"There should be, when the Brazilian national team qualifies for the World Cup, a law that all clubs of the state federations participate in the summoning of players to the national team [sic] in the world cup.

48 BRASIL. Lei $\mathbf{n}^{\circ} \mathbf{6 . 2 5 1}$, de $\mathbf{8}$ de outubro de 1975. Institui normas gerais sobre desportos, e dá outras providências. Diário Oficial da União, Brasília, DF, 09 de outrubro de 1975. Available at: <https://www.planalto.gov. br/ccivil_03/leis/1970-1979/l6251.htm>. Last accessed: 15 mar. 2019.

49 LINHALES, Meily Assbú. A trajetória política do esporte no Brasil: interesses envolvidos, setores excluídos. Belo Horizonte, 1996. 221 f. Dissertação (Mestrado) - Faculdade de Filosofia e Ciências Humanas da Universidade Federal de Minas Gerais. p. 165. 
"Our football is an embarrassment [sic], after so many glories. To begin with the CBF should move
to Brasilia, have more authority, be a registered government agency so there will be no complaints
in the common justice. The sports court must have authority to end abuses, athletes are being paid
unfairly. Some earn too much, others earn too little. There should be a salary table according to the
category of the athlete or club with which he has a contract. Instead of abusive wages the athlete
should have insurance and retirement plans proportional to the length of service. The salary of the
football player is an outrage compared to the Brazilian worker in general in any sector. I believe this
should be studied. The CBF president should be appointed by the President of the Republic."
"- every football player should know how to sing the Brazilian national anthem, otherwise they
should not participate in the games".
"A project limiting salaries of professional athletes. National Shame".
"That sports in Brazil, especially football, be only amateur and not professional, due to the high
wages that players receive and do not deserve."
"Every football club should adopt a kindergarten or a hospital to sponsor."

The category "Professional football", in general lines, also contradicts the constitutional text. While the main objective was to guarantee autonomy to private sports institutions, institutionally detaching them from the interventionism and state centralization in vogue until then ${ }^{50}$, the popular suggestions in this field were more that the State should interfere in the private sphere, especially in the regulation of matters related to professional football and the Brazilian (male) squad of this modality.

However, due to the passionate nature of the suggestions, the category "Professional football" ends up following the categories "Local and personal demands" (Table 3) and "Others" (Table 9) regarding contents that are not pertinent to a national constitution. Much of the popular outrage over players' high salaries was due to the existence of a sports lottery that helped large clubs. These claims, however, are presented within the "Sports Lottery" category, which consists of a mixture of suggestions regarding the allocation of prizes and suggestions in which the term "sports lottery" were mentioned, but which had little or no scope for sports itself, as in the first two examples shown in Table 7.

\section{TABLE 7: EXAMPLES OF SUGGESTIONS CONCERNING THE CATEGORY "SPORTS LOTTERY"}

"Draw by the lottery - why is there no identification of the player on the cards like the model used on the sports lottery cards?".

50 CAMARGOS, Wladimyr Vinycius de Moraes. A constitucionalização do esporte no Brasil - autonomia tutelada: ruptura e continuidade. Brasília, 2017. 188 f. Tese (Doutorado) - Faculdade de Direito da Universidade de Brasília. 
"Remembering that there are a federal lottery, sports lottery, loto, and state lottery, so why not a jogo do bicho [the animal game - a common and illegal gambling practice]?".

"Allocate to social welfare the funds [sic] of the sports lottery, lotto, federal lottery".

"Extinction of all types of lottery in the country - federal - loto and sports. Reason: the "popular" game, in a poor country like ours - removes all (popular) flowing capital. Example: a citizen who would buy [sic] a pair of shoes does not because he bets the money; would buy [sic] a pack of oatmeal for his child does not because he bets the money. And so on with a shirt, food, and even personal hygiene, home, and health. Worst of all is that we are creating a country of addicts. A country is made of people, not addicts".

"I suggest changing the legal instrument that allows the transfer of funds from the sports lottery to football clubs. I suggest that these funds be passed on to public colleges to be applied to sports in general, naturally attending the regional nuances of sports practice. This action, I believe, would bring great advantages in terms of recovering the good habits of youth as well as training athletes for the future."

"Why don't they take half of the lottery prizes to help pay off our international debt?"

The first two examples of the "Sports Lottery" category and the suggestions with a similar content, could also be included in the category "Other references to the term 'sport',' but we decided to maintain them in the first one as they dealt with the theme of lotteries in general. The second category, in turn, deals with suggestions that, for whatever reason, present the term "sport" or related terms, but contain nothing of relevance to it. The examples given in Table 8 illustrate the reasons for creating this category.

\section{TABLE 8: EXAMPLES OF SUGGESTIONS CONCERNING THE CATEGORY “OTHER REFERENCES TO THE TERM ‘SPORT'”'}

"There should be a law to punish, without the minimum right of monetary bail, any corrupt authority, from the highest rank to the football judge, those scoundrels who have been distorting the most beloved sport in Brazil, provoking catastrophes in sports courts, from Amazonas to Chuí".

"In my opinion, I think the college entrance examination should end, because in my view it is just a sports lottery."

"Your Honor, you do not know me, but I've known you for a few years, since 68, in the sports program from the BS Cultura radio, at noon."

"Because many work for sport, and others work so they do not starve."

"Taking the example of national sports, while it was administered publicly, we lived in the dark".

"I am in favor of the death penalty in cases of people who kill for sport and not for self-defense." 
Although this category does not deal with sports demands, it encompasses suggestions related to the search for the descriptors used and, for this reason, in methodological terms, although these suggestions contribute little to the theme of the article, they cannot be discarded. The "Others" category, on the other hand, deals with sport demands, but not previously addressed, as identified in the examples in Table 9.

\begin{tabular}{|c|}
\hline $\begin{array}{l}\text { TABLE 9: EXAMPLES OF SUGGESTIONS CONCE } \\
\text { "- create a ministry that specifically takes care of sports". }\end{array}$ \\
\hline "That boxing, wrestling, karate and all other violent fights be forbidden". \\
\hline $\begin{array}{l}\text { "Physical education: end the compulsory physical education practice for those who take, in parallel } \\
\text { with the last years of the second grade, an industrial apprenticeship course at SENAI." }\end{array}$ \\
\hline $\begin{array}{l}\text { "That teaching in schools be teaching to read and write and not be confused with teaching sport } \\
\text { competition, which is leading our young people to choose the ball and not the book, leave sports to } \\
\text { the Sec. of Sport, back to old times". }\end{array}$ \\
\hline $\begin{array}{l}\text { "Before we think about leisure and sports, we should pay attention to the feeding of these children, } \\
\text { through school, that is, the improvement in school food, and that this be constant in the period of } \\
\text { these children's classes. Having these conditions, then we could think of intelligent children, with } \\
\text { good academic performance, and athletes with prominence among various modalities." }\end{array}$ \\
\hline$" 1$ \\
\hline
\end{tabular}

Although Table 9 presents several examples in some ways contrary to sporting practice, the most prevalent suggestion in the "Others" category was the creation of a sports ministry. As the contrary suggestions varied in their content and the suggestions regarding the ministry were similar, we chose to transcribe only one example of the former and several of the latter. This category also reinforces the illustration of certain unpreparedness by the citizens in relation to the themes pertinent to a Constitution, as discussed by Monclaire ${ }^{51}$.

\section{FINAL CONSIDERATIONS}

Although many suggestions identified in the SAIC do not specifically address sports, while others even dealt with topics that are notoriously inconsistent with insertion in a national constitution, several suggestions, especially in the categories "Amateur sports" and "Right to sport", the fourth and fifth being the most numerous (Table 1), addressed issues of relevance for inclusion in a constitution known as "citizen." Although the minority in relation to the total sum of suggestions, the two categories, due to

51 MONCLAIRE, Stéphane (Org.). A constituição desejada: SAIC: as 72.719 sugestões enviadas pelos cidadãos brasileiros à Assembléia Nacional Constituinte. Vol. 1. Brasília: Senado Federal; Centro Gráfico, 1991. p. 189-193. 
both their material content and the more elaborated content of their texts as well as to the apparently deeper relationship of the proponents with the sports universe, could have been adopted as a way of supplying the absence of participation of entities representing social segments that could claim greater sports democratization.

However, even among the appropriate suggestions in a constitutional text, the general suggestions were very preponderant, with little information about the constituent. The generic tone of the sum of popular suggestions ended up indicating to the constituents that they sought more specific subsidies for the construction of the constitutional text in the entities that are part of the formal sports system, historically involved with sports. In addition, it cannot be disregarded that Article 217 of the CF in a certain way provides general support to sports, contemplating, albeit to a small extent, the most elaborated claims for the right to sport and encouragement of amateur sports.

Given specifically the case of sports in the ANC in relation to Bobbio's direct democracy assumptions ${ }^{52}$, one realizes that such a democracy in its true form does not necessarily offer the best responses in terms of producing a Constitution. However, the lack of more elaborate suggestions cannot silence the importance that the Draft Constitution and the consequent exercise of true direct participation have had for the maturing of democracy, especially after a period of dictatorial rule in Brazil.

Moreover, such a shortage suggests that, in order to have a greater quality of direct participation, it may be necessary to invest in citizen education, clarifying the possible meanings and limits. Offering the concrete means for direct democracy to operate with quality becomes more difficult as constituents and political agents generally demonstrate disdain for popular participation.

Extrapolating the scope of knowledge about how many popular suggestions would have been sufficient to influence the content of sports prediction in the CF, it remains important to point out that, even though the SAIC is a database for the years 1986 and 1987, the reality identified regarding sports seems not to be very outdated in relation to the general framework identified in 2019. Sports were provided for in the CF, but the fields of popular interest and the expected participation of the state seem not to have changed much, as can be observed in relation to the still present demands for courts and sports materials in schools, policies for formation of athletes, state support for sports contexts other than those of elite sports, and state-owned regulation in terms of moralizing professional football, among others.

It is clear that the SAIC is only one of the ways to identify the popular demands in relation to sports in the ANC; in-depth analysis of other forms of direct democracy

52 BOBBIO, Norberto. O futuro da democracia - uma defesa das regras do jogo. Rio de Janeiro: Paz e Terra, 2009. 
and also of the representative being a possibility for future studies. At the same time, the reality identified in relation to the sports theme cannot be generalized in all the construction of the constitutional text, the general analysis of direct and representative democracy in the ANC representing another possibility for future studies.

\section{REFERENCES}

ARAUJO, Silvana Martins de; JARA, laci de Costa; MAGALHÃES, Ywcy Crystiano da Silva. O processo de participação democrática e controle social nas políticas públicas de esporte e lazer. In: ARAUJO, Silvana Martins (Org.). Conselhos estaduais de esporte e lazer no Nordeste brasileiro: participação popular e controle social em questão. São Luís: Edufma, 2011.

ARRETCHE, Marta. Mitos da descentralização: maior democracia e eficiência nas políticas públicas? Revista Brasileira de Ciências Sociais, São Paulo, v. 11, n. 31, p. 44-66, 1996.

ASSEMBLEIA NACIONAL CONSTITUINTE. Ano I - n 33 - Resolução n 2, de 1987. Dispõe sobre o Regimento Interno da Assembléia Nacional Constituinte. Brasília: Assembléia Nacional Constituinte, 1987a.

ASSEMBLEIA NACIONAL CONSTITUINTE. VIII - Comissão da Família, da Educação, Cultura e Esportes, da Ciência e Tecnologia e da Comunicação; VIII-a - Subcomissão da Educação, Cultura e Esportes; Anteprojeto. Brasília: Assembléia Nacional Constituinte, 1987b.

BARDIN, Laurence. Análise de conteúdo. São Paulo: Edições 70, 2011.

BOBBIO, Norberto. O futuro da democracia - uma defesa das regras do jogo. Rio de Janeiro: Paz e Terra, 2009.

BRUST, Cristina; BAGGIO, Isabel Cristina; SALDANHA FILHO, Matheus Francisco. Repensar a gestão das políticas públicas de esporte e lazer: o caso de Santa Maria/RS. Motrivivência, Florianópolis, a. XVIII, n. 27, p. 179-185, dez. 2006.

CÂMARA DOS DEPUTADOS. Sugestão dos Cidadãos. 2017. Available at <http://www2.camara. leg.br/atividade-legislativa/legislacao/Constituicoes_Brasileiras/constituicao-cidada/o-processo-constituinte/sugestao-dos-cidadaos>. Last accessed: 15 mar. 2019.

CAMARGOS, Wladimyr Vinycius de Moraes. A constitucionalização do esporte no Brasil - autonomia tutelada: ruptura e continuidade. Brasília, 2017. 188 f. Tese (Doutorado) - Faculdade de Direito da Universidade de Brasília.

CANAN, Felipe. Compreendendo o direito ao esporte no Brasil - constitucionalização, teleologia e dogmática. Maringá, 2018. 503 f. Tese (Doutorado) - Centro de Ciências da Saúde da Universidade Estadual de Maringá. 
CASTELLANI FILHO, Lino. O Estado brasileiro e os direitos sociais: o esporte. In: GARCIA, Carla Cristina; HÚNGARO, Edson Marcelo; DAMASCENO, Luciano Galvão (Org.). Estado, política e emancipação humana - lazer, educação, esporte, saúde como direitos sociais. Santo André: Alpharrabio, 2008.

COSTA, Lamartine Pereira da. Diagnóstico de Educação Física/Desportos no Brasil. Brasília: Ministério do Planejamento e Coordenação Geral; Ministério da Educação e Cultura, 1971.

DACOSTA, Lamartine (Org.). Atlas do Esporte no Brasil. Rio de Janeiro: CONFEF, 2006.

GIL, Antonio Carlos. Métodos e técnicas de pesquisa social. 6. ed. São Paulo: Atlas, 2008.

GUINMARÃES, Maria do Carmo Lessa. O debate sobre a descentralização de políticas públicas: um balanço bibliográfico. Organizações \& Sociedade, Salvador, v. 9, n. 23, p. 1-17, jan./abr. 2002.

LINHALES, Meily Assbú. A trajetória política do esporte no Brasil: interesses envolvidos, setores excluídos. Belo Horizonte, 1996. 221 f. Dissertação (Mestrado) - Faculdade de Filosofia e Ciências Humanas da Universidade Federal de Minas Gerais.

MINISTÉRIO DA EDUCAÇÃO E CULTURA, Uma nova política para o desporto brasileiro - esporte brasileiro, questão de Estado (Comissão de Reformulação do Desporto - Relatório Conclusivo). Brasília: Secretaria de Educação Física e Desportos do Ministério da Educação e Cultura, 1985.

MINISTÉRIO DO ESPORTE. Diagnóstico nacional do Esporte - Diesporte - Caderno 1. Brasília: Ministério do Esporte, 2015.

MINISTROS EUROPEOS RESPONSABLES DEL DEPORTE. Carta Europea del Deporte para Todos. 1975. Universidad de Córdoba. Available at <https://www.uco.es/deportes/media/documentacion/Carta\%20Europea\%20del\%20Deporte\%20para\%20todos.pdf>. Last accessed: 15 mar. 2019. MONCLAIRE, Stéphane (Org.). A constituição desejada: SAIC: as 72.719 sugestões enviadas pelos cidadãos brasileiros à Assembléia Nacional Constituinte. Vol. 1. Brasília: Senado Federal; Centro Gráfico, 1991.

OLIVEIRA, Mauro Márcio. Fontes de informações sobre a Assembléia Nacional Constituinte de 1987: quais são, onde buscá-las e como usá-las. Brasília: Senado Federal, Subsecretaria de Edições Técnicas, 1993.

PEREIRA, Antônio Kevan Brandão. A concepção democrática de Bobbio: uma defesa das regras do Jogo. Revista Estudos de Política, Campina Grande, v. 1, n.1, p. 53-67, 2012.

SANTOS, Flávia da Cruz. Procurando o lazer na constituinte: sua inclusão como direito social na Constituição de 1988. Campinas, 2011. 178 f. Dissertação (Mestrado). Faculdade de Educação Física da Universidade Estadual de Campinas.

SENADO FEDERAL. Atividade legislativa - bases históricas. 2017. Available at: <http://www. senado.gov.br/atividade/baseshist/bh.asp\#/>. Last accessed: 15 mar. 2019. 
STAREPRAVO, Fernando Augusto. Políticas públicas para o esporte e lazer: conselhos municipais de esporte e lazer e outras formas de participação direta. In: Anais do XV Congresso Brasileiro de Ciências do Esporte e II Congresso Internacional de Ciências do Esporte. Recife: $C B C E$, 2007. 